\title{
Implementation of Marker Image Based Tracking Dental Care and Tooth Type "GG-Q" Based on Augmented Reality
}

\author{
Markarius Paso \\ Software Engineering Technology, \\ Agricultural Polytechnic of \\ Samarinda, Samarinda, 75131, \\ Indonesia \\ Markariuspaso01@gmail.com
}

\author{
Reza Andrea* \\ Software Engineering Technology, \\ Agricultural Polytechnic of \\ Samarinda, Samarinda, 75131, \\ Indonesia \\ reza@bibirdesign.com \\ *Corresponding author
}

\author{
Suswanto \\ Software Engineering Technology, \\ Agricultural Polytechnic of \\ Samarinda, Samarinda, 75131, \\ Indonesia \\ suswanto.attala@gmail.com
}

\begin{abstract}
Augmented Reality (AR) is a technology that allows people to visualize the virtual world as part of the real world. In simple terms AR can be defined as a real environment that is added with virtual objects, this is made possible through certain input devices. Learning media is a tool used in supporting the implementation of the teaching and learning process. In this process, it can be carried out using books or media electronics. One of them is using electronic media in the form of smart phones. In implementing it is applied to the treatment and type of teeth. The types of teeth used are incisors, canines, molars and molars . There are also cavities, tooth structure and dental care. The method used in this research is Marker based tracking. Marker based tracking is a type of Augmented Reality that recognizes a marker and identifies it to add a virtual object to the real environment.
\end{abstract}

Keywords- Augmented Reality, Learning Media, Dental Care and Types of Teeth, Marker Based Tracking

\section{INTRODUCTION}

To achieve optimal dental and oral health, regular maintenance must be carried out. Treatment can be started from paying attention to the diet, not too many foods that contain sugar and sticky foods. Cleaning plaque and remaining food residue by brushing your teeth, techniques and ways to avoid damaging the structure of teeth and gums. Cleaning of tartar and filling of cavities by dentists, as well as extraction of teeth that can no longer be maintained and are focal infections. Regular visits to the dentist every six months whether there are complaints or no complaints. By paying attention to these things, optimal oral health will be achieved.

By using Augmented Reality, it becomes one of the attractions in increasing student interest in learning (Haryani, 2017).

Augmented Reality is a technology that allows people to visualize the virtual world as part of the real world around them effectively so as to make the real world seem to be connected to the virtual world and an interaction can occur (Jacobs, 2010). Augmented reality has the wrong method Anthem ofis Marker based tracking, which is a black and white illustration of a square with thick black and white background. The computer will recognize the position and orientation of the Marker and create a 3D virtual, namely a point $(0,0,0)$ and three axes, namely X, Y and Z (Amaral et al., 2013).

Each dental object has a marker or image tracking book, which is a method that is great for attaching responsive content to physical objects or anchor your scene to a known location in a real-world environment. With Torch, you can set your images to be completely traceable in our visual design environment (Ananda, 2015).

The name of the application called gg-q originated from the chatter from college friends who Initially saying GG-Q, which was thought to be just a joke, has now become the name of an application. And the meaning of GG-Q means My Teeth.

This application will make it easier for the introduction of teeth, especially for everyone, especially for elementary school children. This application can facilitate understanding and knowledge of teeth (Mustaqim, 2016).

In this application, it has a camera feature that is on our smartphone, we need Vuforia SDK which is a framework for making AR, where the data from our Marker will be stored in the Vuforia SDK database. so that it can be integrated with unity.

\section{LITERATURE REVIEW}

A. Teeth

Teeth are hard organs whose main function is to chew food. The teeth are embedded in the alveolar bone, which is a bone that attaches to the surface of your jawbone. Teeth consist of two types of tissue, there is hard tissue on the outside, namely enamel and dentin and soft tissue inside, namely pulp. Email is a hard network of protective teeth.

Picture 1 shows, the pulp is soft tissue in which connective tissue, lymph, nerves and blood vessels are contained. Lymph, nerves and blood vessels enter the tooth through a small hole at the end of the tooth root called the apical foramen. Blood vessels play a role in 
providing nutrition to teeth so that teeth remain strong and healthy, while nerves play a role in delivering stimuli from outside the teeth to your brain so that you can tell if there is damage to the teeth (Erfa, 2015).

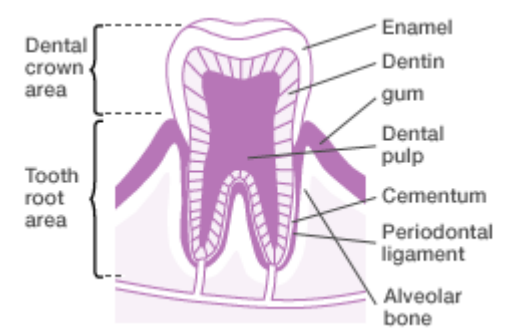

Picture. 1 Dental structures and surrounding networks

\section{B. Augmented Reality}

Augmented Reality is a technique for incorporating the real world into the virtual world. This technique allows an object in the virtual world to be displayed with other objects simultaneously. Rickman Roedavan (2015), There are three principles of Augmented Reality. The first is that AR is an amalgamation of the real and virtual worlds, the second runs interactively in real-time, and the third is integration between objects in three dimensions, namely virtual objects integrated in the real world according to Hunaepi (2016) in Ronald T. Azuma (1997).

\section{Multimedia}

Multimedia, in terms of language, consists of 2 words, namely multi and media. Multi means many or more than one. While media is the plural form of medium, it is also defined as a means, container, or tool. The term multimedia itself can be interpreted as data transmission and manipulation of all forms of information, whether in the form of words, images, videos, music, numbers, or handwriting where in the computer world, this form of information is processed from and in the form of digital data.

\section{Unity $3 D$}

Unity Technologies was built in 2004 by David Helgason, Nicholas Francis and Joachim Ante. This game engine was built on the basis of their concern for indie developers who couldn't buy game engines because they were too expensive. The focus of this company is everyone, especially to build a game. In 2009, Unity was launched for free and in April 2002, Unity reached the highest popularity with more than 1 million registered developers worldwide.

Unity is a game engine that allows you, both individually and in teams, to create a 3D game easily and quickly. Rickman Roedavan (2015). By default, Unity is set up for the creation of First Person Shooting (FPS) genre games, but Unity can also be used to create Role Playing Game (RPG) and Real Time Strategy (RTS) genre games. In addition, Unity is a multiplatform game engine that allows the games you build to be published for various platforms such as Windows, Mac, Android, IOS, PS3 and WII.

\section{E. Blender $3 D$}

According to Ardianto, et al. (2012) Blender is an open source software that is used to create multimedia content, especially 3 dimensions. Blender has several advantages including open source so that it is easy to develop, multi-platform, can be developed easily, is free or free, has complete features, a lightweight application, and a free open community.

\section{F. Marker (Image Based Tracking)}

According to Chari (2008) in the journal Immanuel Valerie Josephine Rombe Allo (2018). Augmented Reality Marker is a type of Augmented Reality that recognizes the Marker and identifies the pattern from the Marker to add a virtual object to the real environment. Marker is an illustration of a black and white rectangle with bold black sides, black pattern in the center and white background.

\section{RESEARCH METHODS}

\section{A. Concept}

Color feature extraction aims to get the mean of RGB value an image. The image has a size of 4000 pixels $x$ 3000 pixels, it is taking by smartphone camera. In this research used 120 images, 80 training images and 40 testing images. The application of clustering based on mobile applications (Lorena, 2019). To get the mean of RGB value an image, user must be upload the image into the application. Mean value of color feature extraction presented in table 1 . The concept stage (conceptualization) is the stage for determining the objectives and who is the program user (identification audience). The objectives and users of endthe program affect the nuances of multimedia as a reflection of the identity of the organization that wants information to reach the end user. User characteristics including user capabilities also need to be considered because they can affect design making (Binanto, 2010).

\section{B. Design}

Design (design) is the stage of making specifications regarding the program architecture, style, appearance, and material or material requirements for the program. Specifications are made as detailed as possible so that at the next stage, namely collecting and assembly materials, new decision makers are no longer needed, it is enough to use the decisions that have been determined at this stage. However, in practice, project work at an early stage will often experience additional materials or reduction of application parts, or other changes.

\section{Material Collecting}

Material Collecting is the stage of collecting materials in accordance with the needs to be done. These materials include clip art images, photographs, animation, video, audio, etc. which can be obtained free of charge or by ordering from other parties according to the design. This stage can be done in parallel with the assembly stage. However, in some cases, the material collecting and 
assembly stages will be carried out linearly and not parallel (Saputro, 2014).

\section{Assembly Assembly}

stage is the stage of making all multimedia objects or materials. Application development is based on the design stage, such as storyboards, flowcharts, and navigation structures.

\section{E. Testing Testing}

phase (testing) is carried out after completing the assembly stage by running an application or program and seeing whether there is an error or not. The first stage at this stage is called the alpha testing stage, where the test is carried out by the manufacturer or the manufacturer's own environment. After passing alpha testing, beta testing involving end use will be carried out. When testing beta, the method used is the User Acceptance Testing (UAT) method. UAT is a testing process carried out by the user with the output of a test result document that can be used as evidence that the software has been received and has met the requirements requested.

\section{F. Distribution}

At this stage, the application will be stored in a storage medium. If there is not enough storage media to accommodate the application, compression of the application will be performed. This stage can also be called the evaluation stage for developing finished products to make them better. The results of this evaluation can be used as input for the concept stage of the next product (Efendi, 2016).

\section{RESULT AND DISCUSSION}

In this study, the objects used were the type of teeth and dental care. Here are the 3D results of the types of teeth and dental treatments.

\section{A. Teeth}

Tooth is an important component in the oral cavity with various functions. Its main function is to chew food, as well as a role in speaking. The teeth with a different role:

1) Dental Fangs

Picture 2 shows, the canines are sharp tooth type and function in the chewing and tearing food. Usually, canines appear between the ages of 16-20 months with the upper canines appearing earlier than the lower canines.

\section{2) Molar}

Picture 3 shows, Molar teeth or large molars are among the largest and most powerful teeth among the other teeth. The molars are used for chewing and grinding food. Generally adults have eight molars, which are divided into four at the top and four at the bottom.

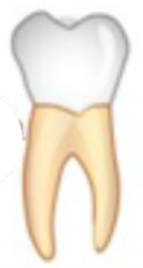

Picture 3. Molar

\section{3) Teeth Premolar Premolar}

Picture 4 shows, type of teeth with a shape bigger than canines and incisors. The function of premolar teeth is to chew and grind food into small pieces for easy swallowing.

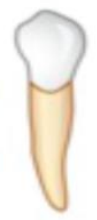

Picture 4. Teeth Premolar

\section{4) Tooth Series}

Picture 5 shows, incisor consists of eight teeth were divided into four on top and four on the bottom. The incisors are located at the front of the mouth which are useful for biting food and are usually the first teeth to appear in babies aged 6 months.

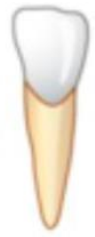

Picture 5. Exciting Teeth Dental

\section{B. The Care}

The method of dental care this time is to brush your teeth properly and well.

1. Brush the front teeth from top to bottom regularly and repeat this several times, this method is only for the front teeth or the part of the teeth that is visible when we smile. Make sure the front teeth are rubbed from top to bottom (not to the left or right side).

2. Brush your teeth in the way of playing-shuffle like a round circle. And repeat this method many times, this also applies to the upper teeth and lower.

3. Brush the inner teeth with a little press and then move upwards. Repeat this method several times until there are no leftovers attached to it, this

Picture 2. Teeth Fangs 
method also applies to the upper and lower left and right teeth.

\section{Assembly Interface}

\section{1) Main Menu Page}

On the main page of the application are given several buttons, namely, the Hint button, Start AR, Quiz and the about button, the profile button is also given a button to exit the application. The main menu page of the application can be seen in Picture 6.

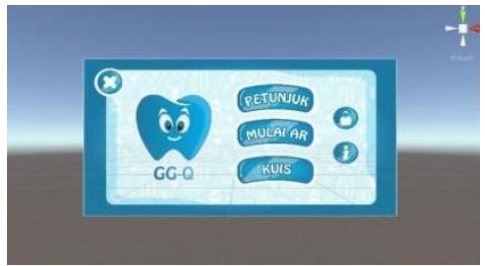

Picture 6. Assembly Design Main Menu Page

\section{2) AR Start Display}

On the AR start page, there are several buttons available, such as the back button, Joystick pack. displays a description panel containing sound buttons as well as an explanation of the objects that appear. Shown in Picture 7.

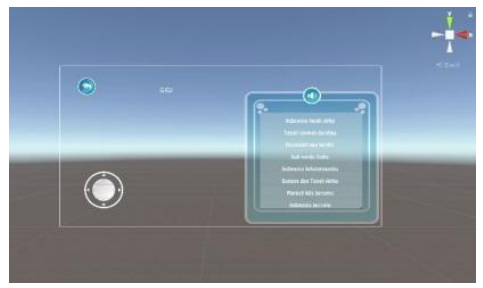

Picture 7. Assembly Design Start Page AR

\section{3) Quiz Display}

Page consists of one type of quiz, namely multiple choices. Quiz in multiple choice form. This quiz page is also given a score feature and output in the form of an animated popup for correct or wrong answers as on the quiz page, for multiple choice quizzes see Picture 8 .

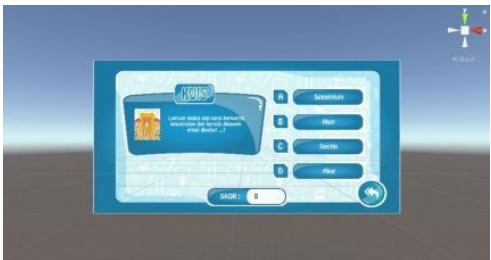

Picture 8. Assembly Design Start AR Page

\section{4) Display Instructions}

The application manual page is created using slides and additional two buttons to go to the next and previous slides. Instructions page can be seen in Picture 9.

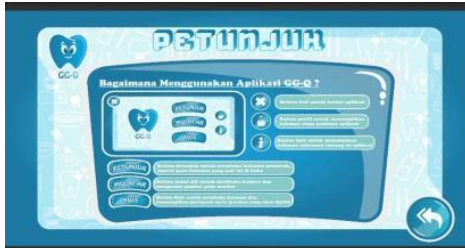

Picture 9. Assembly Design Instructions Page

\section{5) Display Info Pages Info}

This pages are designed to provide information about applications that only display text and images and also provide a button that will be used to download Markers. About page views can be seen in Picture 10.

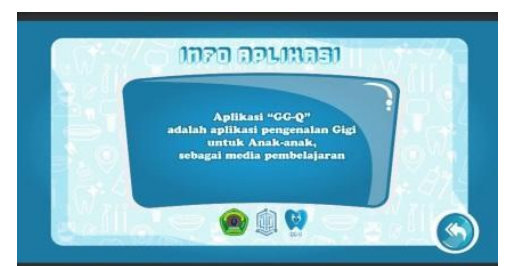

Picture 10. Assembly Design Page Info

6) Display Profile

This Page is designed to provide information about the maker of the application. The display of the about page can be seen in Picture 11 .

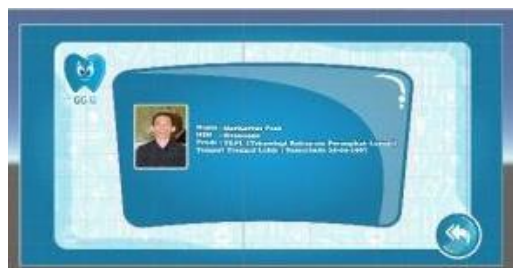

Picture 11. Assembly Design of Profile Page

\section{Testing On Smartphones}

Testing was carried out on 3 smartphones that have different specifications. Testing applications on several different smartphones aims to find out whether the application can run on each smartphone tested. The following is a list of smartphones used to test applications, see table 1 . 
Table 1. List of Smartphone Application Testing

\begin{tabular}{|c|c|c|}
\hline Smartphone Name & \multicolumn{2}{|c|}{ Specifications } \\
\hline \multirow{7}{*}{$\begin{array}{l}\text { (S1) Xiaomi Redmi } 5 \\
\text { Plus }\end{array}$} & \multirow{2}{*}{$\begin{array}{c}\text { Processor } \\
\text { Chipset }\end{array}$} & $\begin{array}{l}\text { : Octa-core Max 2.0GHz } \\
\text { Cortex-A53 }\end{array}$ \\
\hline & & $\begin{array}{l}\text { : Qualcomm MSM8953 } \\
\text { Snapdragon } 625 .\end{array}$ \\
\hline & GPU & : Adreno 506 \\
\hline & RAM & $: 3.00 \mathrm{~GB}$ \\
\hline & Rear Camera & $: 12 \mathrm{MP}$ \\
\hline & Screen Resolution & $\begin{array}{l}: 1080 \text { x } 2160 \text { pixels, } 18: \\
9 \text { ratio }\end{array}$ \\
\hline & Android version & : Android 7.1.2 (nougat) \\
\hline \multirow{7}{*}{$\begin{array}{c}\text { (S2) Samsung Galaxy } \\
\text { A30 }\end{array}$} & Processor & $\begin{array}{l}\text { Octa-core }(2 \times 1.8 \mathrm{GHz} \\
\text { Cortex-A73 \& 6x1.6 GHz } \\
\text { Cortex-A53) }\end{array}$ \\
\hline & Chipset & : Exynos 7904 \\
\hline & GPU & : Mali -G71 MP2 \\
\hline & RAM & $: 4.00 \mathrm{~GB}$ \\
\hline & Rear Camera & $: 16 \mathrm{MP}, 5 \mathrm{MP}$ \\
\hline & Screen Resolution & $\begin{array}{|lll|}1080 \quad x \quad 2340 & \text { pixels, } \\
19.5: 9 \text { ratio } & & \\
\end{array}$ \\
\hline & Android version & : Android 10 \\
\hline \multirow{7}{*}{ S3) Vivo Y12 } & Processor & $\begin{array}{l}: \text { Octa-core }(4 \times 1.95 \text { and } \\
4 \quad x \quad 1.45 \quad \text { GHz } \\
\text { A53) }\end{array}$ \\
\hline & Chipset & \begin{tabular}{|l|} 
Qualcomm SDM439 \\
Snapdragon 439
\end{tabular} \\
\hline & GPU & : Adreno 505 \\
\hline & RAM & $: 3 \mathrm{~GB}$ \\
\hline & Rear Camera & $: 13 \mathrm{MP}, 2 \mathrm{MP}$ \\
\hline & Screen Resolution & $\begin{array}{l}: 720 \times 1520 \text { pixels, } 19: 9 \\
\text { ratio }\end{array}$ \\
\hline & Android version & : Android 8.1 (oreo) \\
\hline
\end{tabular}

\section{E. Functional}

Testing in functional application aims to ensure the software that has been made is as expected. See table 2 .

Table 2. List of Functional Testing Smartphones

\begin{tabular}{|l|l|c|}
\hline Menu & Testing & Description \\
\hline Main Menu & $\begin{array}{l}\text { Displays the main page of the } \\
\text { GG-Q Augmented Reality } \\
\text { application }\end{array}$ & Success \\
\hline $\begin{array}{l}\text { Menu } \\
\text { Instructions }\end{array}$ & $\begin{array}{l}\text { Displays information about } \\
\text { instructions using the GG-Q } \\
\text { AR application }\end{array}$ & Successful \\
\hline $\begin{array}{l}\text { AR Start } \\
\text { Menu }\end{array}$ & $\begin{array}{l}\text { Displays 3D objects, buttons } \\
\text { and descriptions of GG-Q } \\
\text { objects using the camera } \\
\text { Vuforia }\end{array}$ & Successful \\
\hline Quiz Menu & $\begin{array}{l}\text { Displays multiple choice } \\
\text { quizzes }\end{array}$ & Successful \\
\hline $\begin{array}{l}\text { Menu } \\
\text { About }\end{array}$ & $\begin{array}{l}\text { Menu About Displays } \\
\text { information about applications } \\
\text { and developers }\end{array}$ & Successful \\
\hline $\begin{array}{l}\text { Profile } \\
\text { menu }\end{array}$ & $\begin{array}{l}\text { Displays the application } \\
\text { builder's profile page }\end{array}$ & Successfully \\
\hline Exit Menu & $\begin{array}{l}\text { Displays popup options to exit } \\
\text { the application }\end{array}$ & Successful \\
\hline
\end{tabular}

Next functional testing of smartphones that have been tested This test aims to determine whether each smartphone used for testing can carry out every function in the application, both menu and application features, properly according to the expected results. The test results can be seen in table 3 .

Table 3. Functional Testing on Smartphone

\begin{tabular}{|c|c|c|c|c|}
\hline \multirow[t]{2}{*}{ Testing } & \multirow[t]{2}{*}{ Results Expected } & \multicolumn{3}{|c|}{ Smartphones } \\
\hline & & S1 & $\mathrm{S} 2$ & S3 \\
\hline $\begin{array}{l}\text { Install the } \\
\text { application The }\end{array}$ & $\begin{array}{l}\text { application is installed } \\
\text { on the smartphone }\end{array}$ & Yes & Yes & Yes \\
\hline $\begin{array}{l}\text { Run the } \\
\text { application The }\end{array}$ & $\begin{array}{l}\text { application runs and } \\
\text { displays the Main Menu } \\
\text { page }\end{array}$ & Yes & Yes & Yes \\
\hline $\begin{array}{l}\text { Pressing the } \\
\text { menu button } \\
\text { Instructions on } \\
\text { the Main Menu }\end{array}$ & $\begin{array}{l}\text { Shows the application } \\
\text { manual page and the } \\
\text { download button Marker }\end{array}$ & Yes & Yes & Yes \\
\hline $\begin{array}{l}\text { Pressing the } \\
\text { Download } \\
\text { Marker button } \\
\text { on the } \\
\text { instruction page }\end{array}$ & $\begin{array}{l}\text { Shows to the Google } \\
\text { Drive page which } \\
\text { contains Marker images } \\
\text { for download }\end{array}$ & Yes & Yes & Yes \\
\hline $\begin{array}{l}\text { Pressing the AR } \\
\text { Start menu } \\
\text { button on the } \\
\text { Main Menu }\end{array}$ & $\begin{array}{l}\text { Display the AR Start } \\
\text { page, on the AR Start } \\
\text { page there is another } \\
\text { button and when the } \\
\text { Marker is scanned, a 3D } \\
\text { object and planetary } \\
\text { description will appear. }\end{array}$ & Yes & Yes & Yes \\
\hline $\begin{array}{l}\text { Pressing the } \\
\text { Sound feature } \\
\text { button on the } \\
\text { tooth } \\
\text { description } \\
\text { panel }\end{array}$ & $\begin{array}{l}\text { Emits a narrative sound } \\
\text { based on the planet's } \\
\text { description }\end{array}$ & Yes & Yes & Yes \\
\hline $\begin{array}{l}\text { Pressing the } \\
\text { Quiz menu } \\
\text { button on the } \\
\text { Main Menu }\end{array}$ & $\begin{array}{l}\text { Shows a multiple choice } \\
\text { quiz page }\end{array}$ & Yes & Yes & Yes \\
\hline $\begin{array}{l}\text { Clicking the } \\
\text { answer button } \\
\text { on the Multiple } \\
\text { Choice Quiz } \\
\text { page }\end{array}$ & $\begin{array}{l}\text { Provides output in the } \\
\text { form of a score for ja } \\
\text { answer is correct and } \\
\text { animation notification of } \\
\text { answer is wrong or right }\end{array}$ & Yes & Yes & Yes \\
\hline $\begin{array}{l}\text { Pressing button } \\
\text { the About menu } \\
\text { on the Main } \\
\text { Menu }\end{array}$ & $\begin{array}{l}\text { Shows a page about the } \\
\text { application }\end{array}$ & Yes & Yes & Yes \\
\hline $\begin{array}{l}\text { Pressing the } \\
\text { Profile button } \\
\text { on the main } \\
\text { menu }\end{array}$ & $\begin{array}{l}\text { Shows the developer } \\
\text { profile page }\end{array}$ & Yes & Yes & Yes \\
\hline $\begin{array}{l}\text { Pressing the } \\
\text { button Exit On } \\
\text { the main menu }\end{array}$ & $\begin{array}{l}\text { application stops } \\
\text { running }\end{array}$ & Yes & Yes & Yes \\
\hline
\end{tabular}

\section{F. Camera Distance}

Testing The next test is to test the input and output of the application, especially on the Vuforia camera, the input on the camera is a Marker, while the output is in the form of 3D objects and descriptions or other features. The test conducted consists of testing the camera distance (Eka, 2012). The test results can be seen in table 4 . 
Table 4. Camera Distance Testing

\begin{tabular}{|c|c|c|c|}
\hline \multirow{2}{*}{$\begin{array}{l}\text { Camera } \\
\text { Distance }\end{array}$} & \multicolumn{3}{|c|}{ Successful } \\
\hline & $\begin{array}{c}\text { Xiaomi } \\
\text { Redmi 5+ }\end{array}$ & $\begin{array}{c}\text { Samsung } \\
\text { Galaxy A30 }\end{array}$ & Vivo Y12 \\
\hline $5 \mathrm{~cm}$ & No & No & No \\
\hline $10 \mathrm{~cm}$ & Yes & Yes & Yes \\
\hline $20 \mathrm{~cm}$ & Yes & Yes & Yes \\
\hline $30 \mathrm{~cm}$ & Yes & Yes & Yes \\
\hline $40 \mathrm{~cm}$ & Yes & Yes & Yes \\
\hline $50 \mathrm{~cm}$ & Yes & Yes & Yes \\
\hline $60 \mathrm{~cm}$ & Yes & Yes & Yes \\
\hline
\end{tabular}

\section{CONCLUSION}

Based on the results of the research and testing that has been done, it can be concluded that the application implementation uses a method marker base tracking based on Augmented Reality. Tooth types were created using the Unity application with the Vuforia SDK. Both applications are useful in the tracking process in Augmented Reality. Using this implementation can make it easier for users to see the depiction of tooth types in a visual form using a smartphone. In smartphone testing, it was concluded that the three smartphones used at a distance of $5 \mathrm{~cm}$ the $3 \mathrm{D}$ object could not be read while at a distance of $10 \mathrm{~cm}$ to $60 \mathrm{~cm}$ all devices could display the object.

Further research is needed using other body organ objects and using other Augmented Reality methods. With the hope that future application development can be uploaded to the Play store, making it easier for users to access the application.

\section{REFERENCES}

Amaral, G., Bushee, J., Cordani, U. G., KAWASHITA, K., Reynolds, J. H., Almeida, F. F. M. D. E., ... Junho, M. Do C. B. (2013). Implementasi Augmented Reality Image Tracking Visualisai 3d Gedung Rumah Sakit Berbasis Smartphone Android. Journal of Petrology, 369(1), 1689-1699. https://doi.org/10.1017/CBO9781107415324.004

Ananda, T. A., Safriadi, N., Sukamto, A. S., Studi, P., \& Universitas, I. (2015). Penerapan Augmented Reality Sebagai Planet-Planet Di Tata Surya. Jurnal Sistem Dan Teknologi Informasi, 1(1), 1-5.

Binanto, I. (2010). Multimedia Digital - Dasar Teori dan Pengembangannya.

Efendi, Y., Wira, T., \& Khoirunnisa, E. (2016). Penerapan Teknologi Ar (Augmented Reality) Pada Pembelajaran Energi Angin Kelas Iv Sd Di Rumah Pintar Al-Barokah. Studia Informatika, 9(1), 29-47.

Eka Ardhianto, W. H. dan E. W. (2012). Augmented Reality Objek 3 Dimensi dengan Perangkat Artoolkit dan Blender. Dinamik-Jurnal Teknologi ... 17(2), 107-117. Retrieved from http://www.unisbank.ac.id/ojs/index.php/fti 1/article/view/1658

Erfa Eddy, F. N., \& Mutiara, H. (2015). Peranan Ibu dalam Pemeliharaan Kesehatan Gigi Anak dengan Status Karies. Majority, 1-6.
Haryani, P., \& Triyono, J. (2017). Augmented Reality (Ar) Sebagai Teknologi Interaktif Dalam Pengenalan Benda Cagar Budaya Kepada Masyarakat. Simetris: Jurnal Teknik Mesin, Elektro Dan Ilmu Komputer, 8(2), 807. https://doi.org/10.24176/simet.v8i2.1614

Hunaepi, A. (2016). Implementasi Augmented Reality Terhadap Desain Iklan Sebuah Mobil Berbasis Android. Universitas Pamulang.

Lorena, S., \& Purnamasari, J. (2019). Pengembangan Aplikasi Promosi Produk Handphone Menggunakan Teknologi Augmented Reality Pada Mobile Android. Jurusan Teknik Komputer Universitas Komputer Indonesia, 1-8.

Mustaqim, I. (2016). Pemanfaatan Augmented Reality Sebagai Media Pembelajaran. Jurnal Pendidikan Teknologi Dan Kejuruan, 13(2), 1-8. https://doi.org/10.23887/jptk.v13i2.8525

Saputro, R. E., \& Saputra, D. I. S. (2014). Pengembangan Media Pembelajaran Mengenal Organ Pencernaan Manusia Menggunakan Teknologi Augmented Reality. Jurnal Buana Informatika, 6(2), 153-162. https://doi.org/10.24002/j bi.v6i2.404 